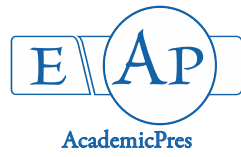

\title{
Maturation and Germination of Date Palm (Phoenix dactylifera L.) Somatic Embryos
}

\author{
Mouaad Amine MAZRI ${ }^{1 *}$, Reda MEZIANI ${ }^{2}$, Ilham BELKOURA ${ }^{3}$, \\ Saida ELMAATAOUI ${ }^{1}$, Boutaïna MOKHLESS ${ }^{3}$, Souad NOUR ${ }^{4}$ \\ ${ }^{1}$ Institut National de la Recherche Agronomique, CRRA-Marrakech, UR Agro-Biotechnologie, Laboratoire de Biotechnologie Végétale, BP 533, \\ Marrakech,Morocco; m.a.mazri@gmail.com (*correspondingauthor); saida.elmaataoui.inass@gmail.com \\ ${ }^{2}$ Institut National de la Recherche Agronomique, CRRA-Errachidia, UR Systèmes Oasiens, Laboratoire National de Culture des Tissus du \\ PalmierDattier, Avenue MoulayAli Cherif, BP 2,Errachidia, Morocco; redameziani@yahoo.fr \\ ${ }^{3}$ Ecole Nationale d'Agriculture, Département des Sciences de Base, Laboratoire de Culture In Vitro, BP S/40, Meknes, \\ Morocco;bilham@enameknes.ac.ma; b.mokbless70@gmail.com \\ ${ }^{4}$ Institut National de la Recherche Agronomique, CRRA-Marrakech, UR Protection des Plantes, BP 533, Marrakech, \\ Morocco; souad.nour1959@gmail.com
}

\begin{abstract}
Maturation and germination of somatic embryos are two crucial steps in the somatic embryogenesis process. Herein, we evaluated the effects of several factors on the maturation and germination of date palm somatic embryos. Globular somatic embryos of cv. 'Najda' were cultured on Murashige and Skoog medium at full strength (MS), half strength (1/2MS), and onethird strength $(1 / 3 \mathrm{MS})$, with or without agar, and supplemented with various concentrations of mannitol, sorbitol, polyethylene glycol (PEG, MW 8000) and abscisic acid (ABA). Our results showed that culture medium strength and texture (liquid or semi-solid), osmotic agents, and the concentration and time of exposure to ABA influence somatic embryo maturation. The highest mean number of mature somatic embryos (106.4 per $100 \mathrm{mg}$ fresh weight callus) was obtained after 3 weeks of culture on full-strength liquid MS medium supplemented with $30 \mathrm{~g} \mathrm{~L}^{-1} \mathrm{PEG}$ and $40 \mu \mathrm{M}$ ABA, followed by 9 weeks of culture on the same medium but without ABA. Somatic embryo germination was achieved by transferring mature embryos to MS medium containing various combinations of 1-naphthalene acetic acid (NAA), 6-benzylaminopurine (BAP) and gibberellic acid $\left(\mathrm{GA}_{3}\right)$. The highest germination rate $(68 \%)$ of somatic embryos occurred in the presence of $0.5 \mathrm{mg} \mathrm{L}^{-1} \mathrm{NAA}$. However, there was no significant difference with the other germination media (54-66\%). Plantlet acclimatization was successfully accomplished, and the survival rate was $80 \%$ after 6 months in the glasshouse. The findings of the present study open new prospects for massive propagation of this bayoud-resistant date palm cultivar.
\end{abstract}

Keywords: embryogenic culture; osmotic agents; Phoenix dactylifera L.; plant growth regulators; somatic embryogenesis

\section{Introduction}

Date palm (Phoenix dactylifera L.) is one of the most important fruit species in the Middle East and North Africa. In the arid and semi-arid regions of Morocco, date palm plays a major role in food providing, ecosystem preservation and agricultural economy (Sedra, 2015). Unfortunately, this species is threatened by bayoud, a serious disease caused by the fungus Fusarium oxysporum $\mathrm{f}$. sp. albedinis, which has decimated more than 10 million palms in Morocco. To date, the only feasible way to fight bayoud is the large-scale propagation of resistant cultivars
(Ferry, 2011). Along this line, several resistant cultivars were selected the National Institute of Agricultural Research of Morocco (INRA), including 'Najda', which is characterized by high fruit quality (Ferry, 2011; Sedra, 2011).

Rapid and large-scale propagation of date palm can be successfully achieved through either direct organogenesis or somatic embryogenesis (Mazri and Meziani, 2015). Direct organogenesis consists of the formation of meristematic buds, followed by shoot bud multiplication then by shoot elongation and rooting (Zaid and Al Kaabi, 2003; Mazri and Meziani, 2013). The somatic embryogenesis process involves the induction of embryogenic calli, somatic embryo 
formation and maturation, and finally plantlet regeneration (Thuzar et al., 2011). Somatic embryogenesis is reputed for its higher propagation potential than that of direct organogenesis. However, the main challenges of somatic embryogenesis are the maturation of somatic embryos and their conversion into complete plantlets.

Among the various approaches used to promote the maturation of somatic embryos, abscisic acid (ABA) has been widely used. It has been reported that $\mathrm{ABA}$ promotes the accumulation of storage proteins in embryos during maturation and enhances embryo quality (Roberts, 1991; Rai et al., 2011). Its beneficial effect on somatic embryo maturation was also observed when used in combination with an osmotically active solute such as polyethylene glycol (PEG) or mannitol (Roberts, 1991; Neto and Otoni, 2003; Yaseen et al., 2013). Other factors such as mineral salts and medium texture (semi-solid or liquid) might influence the growth of somatic embryos (Fki et al., 2003).

Somatic embryo germination and conversion into plantlets is a crucial step that greatly determines the success of the somatic embryogenesis process. Gibberellic acid $\left(\mathrm{GA}_{3}\right)$ has been used to enhance somatic embryo germination and conversion for a wide range of plant species such as soybean (Komatsuda et al., 1992), cotton (Kumria et al., 2003) and bermudagrass ( $\mathrm{Li}$ and $\mathrm{Qu}, 2002)$. In fact, $\mathrm{GA}_{3}$ has been reported to break the dormancy of somatic embryos (Gana, 2011). In many other cases, auxins and cytokinins were used for embryo germination (Bhargava $e t$ al., 2003; Al-Taha et al., 2012).

Studies on the maturation and germination of date palm somatic embryos are scarce. Al-Khayri (2001) and AlKhayri and Al-Bahrany $(2001 ; 2012)$ reported that ABA, PEG-8000, thiamine, biotin and silver nitrate influence somatic embryo growth and elongation, while culture medium strength, and auxin type and concentration affect somatic embryo germination (Al-Khayri, 2003). Regarding cv. 'Najda', a regeneration system through somatic embryogenesis was recently reported (Mazri et al., 2017), in which the positive effect of activated charcoal (AC) on somatic embryo germination was highlighted. Herein, we aimed to evaluate the effects of culture medium strength and texture, osmotically active solutes and $\mathrm{ABA}$ on somatic embryo maturation, and to test the influence of some PGRs on somatic embryo germination and subsequent development into plantlets.

\section{Materials and Methods}

\section{Origin of embryogenic cultures}

Embryogenic cultures (calli with globular embryos; Fig. 1a) of date palm cv. 'Najda' were obtained from adventitious bud segments as fully described by Mazri et al. (2017). To prevent the effects of previous treatments, the cultures were maintained for 3 months on plant growth regulator (PGR)-free Murashige and Skoog medium (Murashige and Skoog, 1962) supplemented with $30 \mathrm{~g} \mathrm{~L}^{-1}$ sucrose (Sigma, Steinheim, Germany), $1 \mathrm{~g} \mathrm{~L}^{-1} \mathrm{AC}$ and $6 \mathrm{~g} \mathrm{~L}^{-1}$ agar (Sigma, St. Louis, MO, USA), with subcultures at 1month intervals. During this phase, somatic embryos that showed signs of development were eliminated. Thus, all the embryogenic cultures used in maturation experiments were containing only globular embryos. The $\mathrm{pH}$ of the culture medium was adjusted to 5.7 before autoclaving at $121{ }^{\circ} \mathrm{C}$ for $25 \mathrm{~min}$, and the cultures were incubated in the dark at $25^{\circ} \mathrm{C}$.

\section{Effects of medium strength and texture on somatic embryo} maturation

In the first experiment, $100 \mathrm{mg}$ fresh weight (FW) calli were cultured on either liquid shaken $(60 \mathrm{rpm})$ or on semisolid Murashige and Skoog medium at full strength (MS), half strength $(1 / 2 \mathrm{MS})$ or one-third strength (1/3MS). All media were supplemented with $30 \mathrm{~g} \mathrm{~L}^{-1}$ sucrose, $1 \mathrm{~g} \mathrm{~L}^{-1} \mathrm{AC}$ and, when semi-solid medium was required, $6 \mathrm{~g} \mathrm{~L}^{-1}$ agar was added. The $\mathrm{pH}$ of all media was adjusted to 5.7 then $20 \mathrm{ml}$ aliquots of each medium were dispensed into $300 \mathrm{ml}$ glass jars before autoclaving at $121{ }^{\circ} \mathrm{C}$ for $25 \mathrm{~min}$. All cultures were maintained in the dark at $25^{\circ} \mathrm{C}$ for 12 weeks with transfers to fresh medium at 3-weeks intervals.

\section{Effects of osmotic agents on somatic embryo maturation}

In the second experiment, $100 \mathrm{mg}$ FW callus was disintegrated with a scalpel and cultured on $20 \mathrm{ml}$ liquid MS medium supplemented with $30 \mathrm{~g} \mathrm{~L}^{-1}$ sucrose and $1 \mathrm{~g} \mathrm{~L}^{-1}$ AC, over a shaker $(60 \mathrm{rpm})$ for 12 weeks. To test the effects of osmotic agents on somatic embryo maturation, various concentrations $\left(10,30\right.$ and $\left.50 \mathrm{~g} \mathrm{~L}^{-1}\right)$ of mannitol, sorbitol or polyethylene glycol (PEG, MW 8000) were added to the culture medium. The $\mathrm{pH}$ of all media was adjusted to 5.7 before autoclaving at $121^{\circ} \mathrm{C}$ for $25 \mathrm{~min}$. The cultures were maintained in the dark at $25^{\circ} \mathrm{C}$ and transferred onto fresh medium at 3-weeks intervals.

\section{Effects of $A B A$ on somatic embryo maturation}

In the third experiment, $100 \mathrm{mg}$ FW callus was disintegrated with a scalpel and cultured for 3 months on 20 $\mathrm{ml}$ liquid MS medium supplemented with $30 \mathrm{~g} \mathrm{~L}^{-1}$ sucrose and $1 \mathrm{~g} \mathrm{~L}^{-1} \mathrm{AC}$. Based on the results from the previous experiment, $30 \mathrm{~g} \mathrm{~L}^{-1}$ PEG was added to the culture medium. The culture medium was also supplemented with different concentrations of ABA (10-50 umol) either for 3 weeks (short exposure) or for 12 weeks (long exposure). The $\mathrm{pH}$ of all media was adjusted to 5.7 before autoclaving at $121^{\circ} \mathrm{C}$ for $25 \mathrm{~min}$. The cultures were maintained for 12 weeks in the dark over a shaker $(60 \mathrm{rpm})$ at $25^{\circ} \mathrm{C}$ and transferred onto fresh medium at 3-weeks intervals.

\section{Somatic embryo germination and plantlet acclimatization}

Somatic embryos of tubular shape, which have similar size of fully mature zygotic embryos (at least $1 \mathrm{~cm}$ in length) (Al-Khayri and Al-Bahrany, 2012), were considered mature.

Mature somatic embryos were cultured on MS medium supplemented with $30 \mathrm{~g} \mathrm{~L}^{-1}$ sucrose, $1 \mathrm{~g} \mathrm{~L}^{-1} \mathrm{AC}, 6 \mathrm{~g} \mathrm{~L}^{-1}$ agar and various concentrations $\left(0,0.5\right.$ or $\left.1 \mathrm{mg} \mathrm{L}^{-1}\right)$ of 1 naphthalene acetic acid (NAA), 6-benzylaminopurine (BAP) and gibberellic acid $\left(\mathrm{GA}_{3}\right)$. Prior to autoclaving, the $\mathrm{pH}$ of all media was adjusted to 5.7 then the media were dispensed to jars, with $20 \mathrm{ml}$ of medium per jar. The cultures were incubated at $25^{\circ} \mathrm{C}$ under a $16 \mathrm{~h}$ photoperiod (40 $\mu \mathrm{mol} \mathrm{m} \mathrm{m}^{-2} \mathrm{~s}^{-1}$ light intensity) for 5 months and transferred onto fresh medium at 1-month intervals. 
88

The developed plantlets were transferred to the glasshouse as described by Mazri et al. (2018). The root system was washed with tap water then soaked for $15 \mathrm{~min}$ in a solution of $1 \mathrm{~g} \mathrm{~L}^{-1}$ systemic fungicide (Pelt 44 PM; Bayer CropScience Bayer Maghreb SA, Casablanca, Morocco). Thereafter, the plantlets were transferred to plastic bags containing a 1:1 mixture of peat-gravel substrate then placed in a tunnel covered with transparent polyethylene for 2 weeks to maintain high relative humidity $(98 \% \mathrm{RH})$. The plantlets were then exposed to glasshouse conditions $\left(27^{\circ} \mathrm{C}\right.$; $70 \% \mathrm{RH}$ ) by gradually removing the polythene bag.

\section{Recordings and statistical analysis}

During the maturation experiments, each jar containing $100 \mathrm{mg}$ FW callus was considered as an experimental unit and replicated 10 times, and we recorded the mean number of mature somatic embryos per $100 \mathrm{mg}$ FW callus after 12 weeks. During the germination phase, each jar containing 10 mature somatic embryos was considered an experimental unit and each treatment consisted of 10 replications. The frequency of germinated somatic embryos converted into plantlets was calculated after 3 months. The survival rate of plantlets was recorded after 6 months in the glasshouse.

Data presented are means \pm standard deviation $(\mathrm{SD})$. All data were analyzed using analysis of variance (ANOVA). The adopted model was Completely Randomized Design (CRD) and means with significant differences were separated using the Student-Newman-Keuls test (SNK) at $p \leq 0.05$ level. Prior to analysis, percentage data were arcsinetransformed. All of the statistics were performed with the software SPSS for Windows v. 21.0 (SPSS Inc., IBM, Chicago, IL, USA).

\section{Results}

Effects of medium strength and texture on somatic embryo maturation

After transferring embryogenic cultures to maturation media, globular embryos started to grow and to form a tubular shape. After 12 weeks of culture, the embryogenic calli produced 11.8, 12.4 and 16.2 mature embryos per 100 mg FW callus on semi-solid 1/3MS, 1/2MS and MS medium, respectively. When cultured in liquid state, the mean number of mature somatic embryos produced per $100 \mathrm{mg} \mathrm{FW}$ callus ranged from 29.6 to 41.6, depending on medium strength (Table 1). The highest number of mature somatic embryos was observed on liquid MS medium. All tubular embryos were white to yellow and opaque irrespective of medium strength and its texture.

\section{Effects of osmotic agents on somatic embryo maturation}

Supplementing the culture medium with an osmotic agent (sorbitol, mannitol or PEG) stimulated somatic embryo development (Table 2). Among the various types and concentrations of osmotic agents tested, the highest number of mature somatic embryos (83.5) was obtained on liquid MS medium containing $30 \mathrm{~g} \mathrm{~L}^{-1}$ PEG. The rise in PEG concentration to $50 \mathrm{~g} \mathrm{~L}^{-1}$ did not result in a significant variation in the number of mature somatic embryos $(p>$ $0.05)$.

Table 1. Effect of culture medium strength and texture on somatic embryo maturation

\begin{tabular}{ccc}
\hline Medium strength & Agar supplementation & Number of mature somatic embryos per 100 mg FW callus \\
\hline MS & + & $16.2 \pm 1.68 \mathrm{~b}$ \\
MS & + & $41.6 \pm 5.31 \mathrm{e}$ \\
$1 / 2 \mathrm{MS}$ & - & $12.4 \pm 2.17 \mathrm{a}$ \\
$1 / 2 \mathrm{MS}$ & + & $33.8 \pm 3.35 \mathrm{~d}$ \\
$1 / 3 \mathrm{MS}$ & - & $11.8 \pm 1.68 \mathrm{a}$ \\
$1 / 3 \mathrm{MS}$ & $29.6 \pm 5.35 \mathrm{c}$ \\
\hline
\end{tabular}

Values correspond to means \pm standard deviation. Means followed by the same letter are not significantly different $(P>0.05)$ by Student-Newman-Keuls test.

$M S$ Murashige and Skoog medium at full strength

$1 / 2 M S$ Murashige and Skoog medium at half-strength

1/3MS Murashige and Skoog medium at one-third strength

(+) The culture medium was supplemented with $6 \mathrm{~g} \mathrm{~L}^{-1}$ agar (semi-solid medium)

(-) Agar-free medium (liquid medium agitated at $60 \mathrm{rpm}$ ).

Table 2. Effect of osmotic agents on somatic embryo maturation after 12 weeks of culture

\begin{tabular}{cccc}
\hline & Osmotic agent type and concentration $\left(\mathrm{g} \mathrm{L}^{-1}\right)$ & & Number of mature somatic embryos per 100 mg FW callus \\
\hline Sorbitol & Mannitol & PEG & $41.6 \pm 5.31 \mathrm{a}$ \\
\hline 0 & 0 & 0 & $46.8 \pm 3.73 \mathrm{a}$ \\
10 & 0 & 0 & $68.0 \pm 9.55 \mathrm{c}$ \\
50 & 0 & 0 & $57.2 \pm 3.48 \mathrm{~b}$ \\
0 & 0 & 0 & $44.8 \pm 4.98 \mathrm{a}$ \\
0 & 10 & 0 & $58.7 \pm 4.44 \mathrm{~b}$ \\
0 & 30 & 0 & $47.3 \pm 6.25 \mathrm{a}$ \\
0 & 50 & 10 & $67.1 \pm 5.83 \mathrm{c}$ \\
\hline
\end{tabular}

Values correspond to means + standard deviation. Means followed by the same letter are not significantly different $(P>0.05)$ by Student-Newman-Keuls test. PEG polyethylene glycol-8000. 
However, it resulted in the browning of somatic embryos. The use of sorbitol and mannitol at the concentration of $30 \mathrm{~g} \mathrm{~L}^{-1}$ showed 68 and 58.7 mature somatic embryos per $100 \mathrm{mg}$ FW callus, respectively. This is significantly $(p \leq 0.05)$ lower than the mean number of mature somatic embryos obtained on PEG-containing medium at that same concentration.

Effects of ABA on somatic embryo maturation

After 3 to 12 weeks of culture (short- and long-duration exposure) in ABA-containing media, it was found that this PGR can significantly promote or inhibit embryo growth and maturation depending on its concentration and the duration of exposure (Table 3). Our results showed that culturing embryogenic calli in an ABA-containing medium for 12 weeks hampered somatic embryo maturation (15.623.1 mature somatic embryos per $100 \mathrm{mg} \mathrm{FW}$ callus). On the other hand, the mean number of mature somatic embryos significantly increased to 106.4 when calli were cultured on $40 \mu \mathrm{mol}$ ABA-containing medium for 3 weeks followed by culture in ABA-free medium for 9 weeks (Fig. 1b). Increasing the concentration of $A B A$ to $50 \mu \mathrm{mol}$ (short exposure treatment) did not improve somatic embryo maturation.
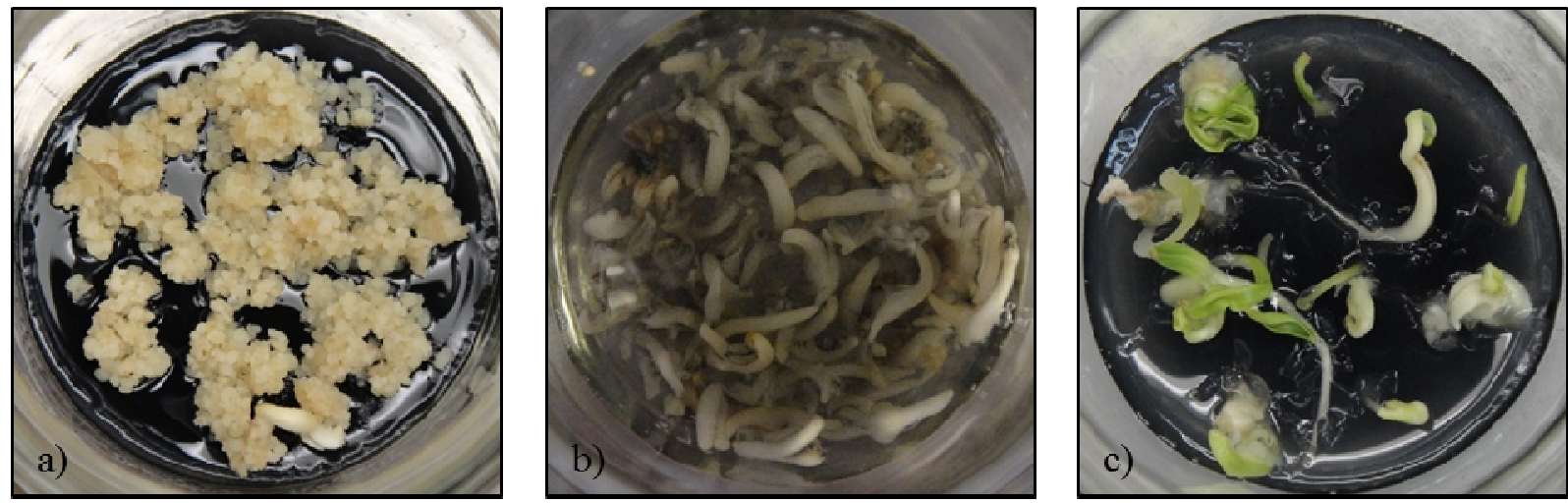

Fig. 1. Maturation and germination of date palm cv. Najda somatic embryos. a Embryogenic cultures used in the present study. $b$ Somatic embryo maturation after 3 weeks of culture on MS medium supplemented with $30 \mathrm{~g} \mathrm{~L}^{-1}$ PEG and $40 \mu \mathrm{mol}$ ABA followed by 9 weeks of culture on the same medium but without ABA. c Somatic embryo germination after 6 weeks of culture on MS medium supplemented with $0.5 \mathrm{mg} \mathrm{L}^{-1} \mathrm{NAA}$
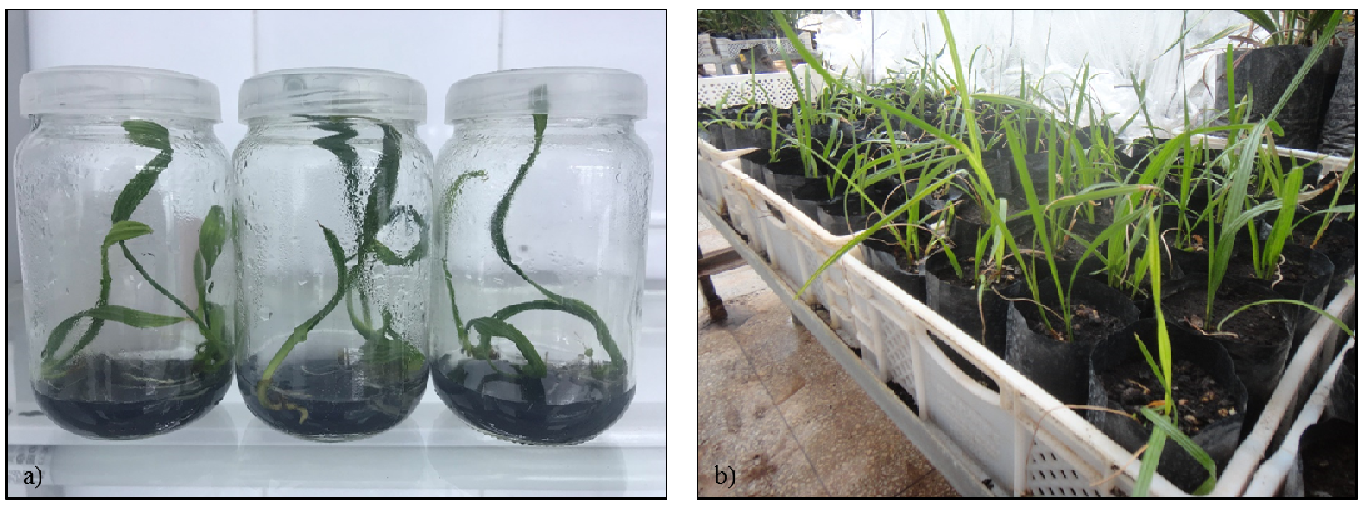

Fig. 2. Plantlet regeneration and acclimatization. a Plantlets obtained after 5 months of culture on PGR-free MS medium. b Plantlet survival after 6 months in the glasshouse 
90

Table 3. Effects of ABA concentration and the duration of culture in ABA-containing medium on somatic embryo maturation after 12 weeks of culture

\begin{tabular}{|c|c|c|c|}
\hline $\begin{array}{l}\text { Duration of culture in ABA- } \\
\text { containing medium }\end{array}$ & $\begin{array}{c}\text { Duration of culture in ABA-free } \\
\text { medium }\end{array}$ & ABA concentration $(\mu \mathrm{mol})$ & $\begin{array}{l}\text { Number of mature somatic embryos per } \\
100 \mathrm{mg} \text { FW callus }\end{array}$ \\
\hline 0 week & 12 weeks & 0 & $83.5 \pm 7.64 b$ \\
\hline 3 weeks & 9 weeks & 10 & $85.2 \pm 8.57 b$ \\
\hline 3 weeks & 9 weeks & 20 & $98.4 \pm 9.65 c$ \\
\hline 3 weeks & 9 weeks & 30 & $97 \pm 9.26 \mathrm{c}$ \\
\hline 3 weeks & 9 weeks & 40 & $106.4 \pm 10.67 d$ \\
\hline 3 weeks & 9 weeks & 50 & $88.7 \pm 7.39 b$ \\
\hline 12 weeks & 0 week & 10 & $23.1 \pm 6.41 \mathrm{a}$ \\
\hline 12 weeks & 0 week & 20 & $19.7 \pm 5.47 a$ \\
\hline 12 weeks & 0 week & 30 & $18.7 \pm 3.23 \mathrm{a}$ \\
\hline 12 weeks & 0 week & 40 & $19.1 \pm 3.57 \mathrm{a}$ \\
\hline 12 weeks & 0 week & 50 & $15.6 \pm 3.16 a$ \\
\hline
\end{tabular}

Values correspond to means \pm standard deviation. Means followed by the same letter are not significantly different $(P>0.05)$ by Student-Newman-Keuls test. $A B A$ abscisic acid

Table 4. Effects of plant growth regulators on somatic embryo germination

\begin{tabular}{|c|c|c|c|c|c|}
\hline \multicolumn{3}{|c|}{ Plant growth regulators $\left(\mathrm{mg} \mathrm{L}^{-1}\right)$} & \multirow{2}{*}{$\begin{array}{c}\text { Somatic embryos } \\
\text { turned brown and died } \\
(\%)\end{array}$} & \multirow{2}{*}{$\begin{array}{c}\text { Somatic embryos forming } \\
\text { shoots only }(\%)\end{array}$} & \multirow{2}{*}{$\begin{array}{c}\text { Somatic embryos converted } \\
\text { into plantlets (\%) }\end{array}$} \\
\hline NAA & BAP & $\mathrm{GA}_{3}$ & & & \\
\hline 0 & 0 & 0 & $36 \pm 5.47 c$ & $10 \pm 0 \mathrm{ab}$ & $54 \pm 5.47 a$ \\
\hline 0 & 0.5 & 0 & $14 \pm 5.47 \mathrm{ab}$ & $28 \pm 8.36 b$ & $58 \pm 10.95 a$ \\
\hline 0 & 1 & 0 & $16 \pm 5.47 \mathrm{ab}$ & $28 \pm 8.36 b$ & $56 \pm 5.47 a$ \\
\hline 0.5 & 0 & 0 & $22 \pm 8.36 \mathrm{abc}$ & $10 \pm 0 \mathrm{ab}$ & $68 \pm 8.36 a$ \\
\hline 0.5 & 0.5 & 0 & $12 \pm 4.47 \mathrm{ab}$ & $24 \pm 11.40 \mathrm{ab}$ & $64 \pm 8.94 \mathrm{a}$ \\
\hline 0.5 & 1 & 0 & $16 \pm 5.47 \mathrm{ab}$ & $20 \pm 15.81 \mathrm{ab}$ & $64 \pm 19.49 a$ \\
\hline 1 & 0 & 0 & $20 \pm 7.07 \mathrm{ab}$ & $18 \pm 4.47 \mathrm{ab}$ & $62 \pm 4.47 a$ \\
\hline 1 & 0.5 & 0 & $10 \pm 7.07 \mathrm{a}$ & $26 \pm 5.47 b$ & $64 \pm 11.40 a$ \\
\hline 1 & 1 & 0 & $10 \pm 7.07 \mathrm{a}$ & $30 \pm 10 b$ & $60 \pm 15.81 \mathrm{a}$ \\
\hline 0 & 0 & 0.5 & $26 \pm 5.47 b c$ & $8 \pm 4.47 a$ & $66 \pm 5.47 a$ \\
\hline 0 & 0 & 1 & $22 \pm 4.47 \mathrm{abc}$ & $14 \pm 11.40 \mathrm{ab}$ & $64 \pm 13.41 \mathrm{a}$ \\
\hline
\end{tabular}

Values correspond to means \pm standard deviation. Means followed by the same letter are not significantly different $(P>0.05)$ by Student-Newman-Keuls test.

$N A A$ 1-naphthalene acetic acid, $B A P$ 6-benzylaminopurine, $G A 3$ gibberellic acid

\section{Discussion}

Maturation and germination of somatic embryos are two major steps in the somatic embryogenesis process. It is well known that in many plant species, these two phases constitute a bottleneck and may hamper the whole regeneration process. In the present study, we evaluated the effects of culture medium strength and texture, PGRs and osmotically active solutes on the maturation and germination of date palm somatic embryos. Our results showed a significant effect of medium strength and texture on somatic embryo maturation. In fact, MS medium at full strength was more suitable for somatic embryo maturation than $1 / 2 \mathrm{MS}$ and $1 / 3 \mathrm{MS}$. The higher concentration of macronutrients contained in full-strength MS medium seems to match the nutritional requirement for efficient maturation of date palm cv. 'Najda' somatic embryos. Our results indicated also that the number of mature somatic embryos drastically increases when liquid media are used. This confirms previous results on date palm cultivar 'Deglet Nour' by Fki et al. (2003). These authors indicated that the number of mature embryos per $100 \mathrm{mg}$ FW callus was 200 after one month of culture on liquid medium while it was only 10 on semi-solid medium. Along this line, it was reported that liquid media allow faster growth than the solid ones (Thorpe et al., 2008). This is due to the fact that the uptake of nutrients is more efficient in liquid media than in semi-solid media (Lorenzo et al., 1998). It was also reported that culturing embryogenic cultures in suspension allows better synchronization of somatic embryos (Von Arnold, 2008).

In addition to their nutritional contribution during somatic embryogenesis, carbon sources serve as an osmoticum since they affect water potential of the medium and control the movement of water and minerals into plant tissues (Neto and Otoni, 2003; Shoji et al., 2006). The osmotically active solutes mannitol, sorbitol and PEG have been frequently employed for their osmotic regulator role during somatic embryogenesis (Neto and Otoni, 2003). However, it was reported that sufficient sucrose should also be present to supply the energy requirement of the tissues (Thorpe et al., 2008). Mannitol, sorbitol and PEG have been used in many plant species to stimulate somatic embryo maturation. Our results showed that the use of PEG at the concentration of $30 \mathrm{~g} \mathrm{~L}^{-1}$ significantly increased the number of mature somatic embryos. This is in good agreement with our previous findings in date palm cv. 'Mejhoul' (Mazri et al., 2018). In fact, the non-permeating osmotic PEG was reported to enhance somatic embryo maturation by creating a culture environment similar to desiccation (Zhang et al., 2007). 
Abscisic acid is involved in the regulation of many physiological processes of plants; e.g., it promotes the maturation of somatic embryos, improves embryo quality, prevents precocious germination and reduces the process of secondary embryogenesis (Rai et al., 2011). It was also reported that ABA plays an important role in the accumulation of storage reserves and the synchronization of somatic embryo maturation (Misra, 1994). Along this line, ABA has been widely used in many plant species. Vahdati $e t$ al. (2008) reported that in Juglans regia L., the size of somatic embryos increased with increasing $\mathrm{ABA}$ concentration to $2 \mathrm{mg} \mathrm{L}^{-1}$. However, at the concentration of $5 \mathrm{mg} \mathrm{L}^{-1}$, a reverse effect was observed. In Pinus densiflora, Shoji et al. (2006) found that $30 \mu \mathrm{M} \mathrm{ABA}$ is the optimal concentration for somatic embryo maturation while higher concentrations decrease or even inhibit somatic embryo maturation. Studies on the effects of ABA concentration on date palm somatic embryo maturation are scarce. Zouine et al. (2005) reported that in date palm cvs. Jihel and bousthami noir, the somatic embryos cultured on maturation medium supplemented with $10^{-5} \mathrm{~mol} A B A$ accumulated more sugars than those cultured on other media. Al-Khayri and Al-Bahrany (2012) indicated that at high levels of ABA (50-100 umol), the growth of somatic embryos of cv. 'Nabout Saif was hampered and that the majority of embryos remained at the small globular stage. In date palm cv. 'Mejhoul', using ABA at the concentration of 10-50 $\mu \mathrm{mol}$ did not promote somatic embryo maturation (Mazri et al., 2018). This is in good agreement with the present study. In fact, our results revealed that somatic embryo maturation was enhanced only after a short time of culture (3 weeks) on an ABA-supplemented medium followed by 9 weeks of culture on ABA-free medium.

The findings of this investigation showed that the combination of $40 \mu \mathrm{mol} \mathrm{ABA} \mathrm{(short} \mathrm{exposure)} \mathrm{and} 30 \mathrm{~g} \mathrm{~L}^{-1}$ PEG resulted in the highest number of mature somatic embryos. The beneficial effect of ABA-PEG combination on somatic embryo maturation was reported in other plant species (Thorpe et al., 2008). According to Rai et al. (2011) and Yaseen et al. (2013), combining ABA and PEG improves the frequency and synchrony of somatic embryos and stimulates their maturation.

The highest rates (66-68\%) of somatic embryo germination were observed on media supplemented with $0.5 \mathrm{mg} \mathrm{L}^{-1} \mathrm{NAA}$ or $0.5 \mathrm{mg} \mathrm{L}^{-1} \mathrm{GA}_{3}$. These two PGRs have been widely used for somatic embryo germination. In addition, NAA was used successfully in some date palm cultivars for somatic embryo germination and conversion into plantlets. For example, in cvs. 'Boufeggous' $\left(1 \mathrm{mg} \mathrm{L}^{-1}\right)$ (Othmani et al., 2009) and 'Deglet Bey' (0.1 mg L-1; Othmani et al., 2018). Regarding gibberellins, it was reported that they are involved in many processes during plant growth and development, including dormancy release and seed germination (Linkies and Leubner-Metzger, 2012).

Our results showed that supplementing the germination medium with PGRs promotes somatic embryo germination (up to 68\%), but with no significant difference with PGRfree medium (54\%). In date palm cv. 'Mejhoul', the combination of NAA and BAP significantly increased the germination rate to $52 \%$, while this rate was $8 \%$ in those cultured on PGR-free medium (Mazri et al., 2018). These conflicting results might be explained by a genotype effect, since responses to culture medium composition are highly variable, depending on the cultivar. Along this line, in some date palm cultivars, somatic embryo germination and conversion into plantlets was successfully achieved in a PGR-free medium (Zouine et al., 2005; Sané et al., 2012). However, in other cases, PGRs were used for somatic embryo germination (Al-Khayri, 2003; Zouine and El Hadrami, 2007). Based on our results, we suggest a PGRfree medium for the germination of cv. 'Najda' somatic embryos since there is no significant difference with media containing PGRs. This will be cost-effective for large-scale application and will minimize the risk of undesirable somaclonal variation.

The genotype effect was observed also in somatic embryo germination rates. In the present study, a germination rate of up to $68 \%$ was obtained. Boufis $e t$ al. (2014) reported a germination rate of $35.2 \%$ in cv. 'Degla Beida'. In cvs. 'Ahmar', 'Amsekhsi', 'Tijib', and 'Amaside', Sané et al. (2012) reported a germination rate of $82 \%$. In cv. 'Boufeggous', the germination rate of somatic embryos was 83\% (Othmani et al., 2009) while Ibrahim et al. (2012) reported germination rates of 83.3 and $60 \%$ in cvs. 'Malkaby' and 'Barhee', respectively. Some treatments such as desiccation and cold hardening were suggested to enhance somatic embryo germination (Boufis et al., 2017; Shareef, 2017).

Plantlet acclimatization has been successfully achieved with a survival rate of $80 \%$. This is in good agreement with previous studies on date palm micropropagation. In fact, high survival rates (80-97.5\%) were reported in plantlets obtained either through organogenesis or somatic embryogenesis (Meziani et al., 2015; 2016; Mazri et al., 2016; 2017).

\section{Conclusions}

In the present work, several factors that affect somatic embryo maturation and germination were evaluated. The incorporation of ABA (short exposure) and PEG in MS liquid medium resulted in the highest number of mature somatic embryos while PGRs did not improve significantly the rate of somatic embryo germination. Although the increase in the rate of somatic embryo germination in PGRcontaining media was not significant statistically, it was noteworthy and warrants further studies. The findings of this research will be useful for rapid and large-scale propagation of date palm cv. 'Najda', a genotype characterized by high fruit quality and bayoud diseaseresistance. We are currently evaluating the genetic conformity of the obtained plantlets by using molecular markers.

\section{Acknowledgements}

This work was supported by the MESRSFC and CNRST (Morocco), project number PPR2/2016/36. 


\section{References}

Al-Khayri JM (2001). Optimization of biotin and thiamine requirements for somatic embryogenesis of date palm (Phoenix dactylifera L.). In Vitro Cellular \& Developmental Biology - Plant 37(4):453-456.

Al-KhayriJM(2003).In vitro germination of somatic embryos in date palm: effect of auxin concentration and strength of MS salts. Current Science 84:680-683

Al-Khayri JM, Al-Bahrany AM (2001). Silver nitrate and 2isopentyladenine promote somatic embryogenesis in date palm (Phoenix dactylifera L.). Scientia Horticulturae 89(4):291-298.

Al-Khayri JM, Al-Bahrany AM (2012). Effect of abscisic acid and polyethylene glycol on the synchronization of somatic embryo development in date palm (Phoenix dactylifera L.). Biotechnology 11(6):318-325.

Al-Taha HA, Jasim AM, Abbas MF (2012). Somatic embryogenesis and plantlet regeneration from nucleus tissues of local orange (Citrus sinensis (L.) Osbeck). Acta Agriculturae Slovenica 99:185-189.

Bhargava SC, Saxena SN, Sharma R (2003).In vitromultiplication ofPhoenix dactylifera (L). Journal of Plant Biochemistry and Biotechnology 12(1):43-47.

Boufis N, Khelifi-Slaoui M,Djillali Z, ZaouiD, Morsli A,... KhelifiL (2014). Effects of growth regulators and types of culture media on somatic embryogenesis in date palm (Phoenix dactylifera L. cv. 'Degla Beida'). Scientia Horticulturae 172:135-142.

Boufis N, Titouh K, Khelifi L (2017). Desiccation-enhanced maturation and germination of date palm somatic embryos derived from cell suspension culture. In: Al-KhayriJM,Jain SM, Johnson DV (Eds). Date palm biotechnology protocols Volume I. Springer Nature, New York pp 107-117.

Ferry M (2011). Potential of date palm micropropagation for improving small farming systems. In: Jain SM, Al-Khayri JM, Johnson DV (Eds). Date palm biotechnology. Springer, Dordrecht pp 15-28.

Fki L, Masmoudi R, Drira N, Rival A (2003). An optimised protocol for plant regeneration from embryogenic suspension cultures of date palm, Phoenix dactylifera L., cv. 'Deglet Nour'. Plant Cell Reports 21(6):517524.

Gana A (2011). The role of synthetic growth hormones in crop multiplication and improvement. African Journal of Biotechnology 10(50):10330-10334.

Ibrahim IA, Hassan MM, Taha RA (2012). Partial desiccation improves plant regeneration of date palm in vitro cultures. Wudpecker Journal of Agricultural Research 1(6):208-214.

Komatsuda T, Lee W, Oka S (1992). Maturation and germination of somatic embryos as affected by sucrose and plant growth regulators in soybeans Glycine gracilis Skvortz and Glycine max (L.) Merr. Plant Cell Tissue and Organ Culture 28(1):103-113.

Kumria R, Sunnichan VG, Das DK, Gupta SK, Reddy VS, ... Leelavathi S (2003). High-frequency somatic embryo production and maturation into normal plant in cotton (Gossypium hirsutum) through metabolic stress. Plant Cell Reports 21(\&):635-639.

LiL, Qu R(2002).In vitro somatic embryogenesis in turf-type bermudagrass: roles of abscisic acid and gibberellic acid, and occurrence of secondary somatic embryogenesis. Plant Breeding 121(2):155-158.

Linkies A, Leubner-Metzger G (2012). Beyond gibberellins and abscisic acid: how ethylene and jasmonates control seed germination. Plant Cell Reports31(2):253-270.

Lorenzo JC, Gonzalez BL, Escalona M, Teisson C, Espinosa P, Borroto C (1998). Sugarcane shoot formation in an improved temporary immersion system. Plant Cell Tissue and Organ Culture 54(3):197200.

Mazri MA, Meziani R(2013). An improved method for micropropagation and regeneration of date palm (Phoenix dactylifera L.). Journal of Plant Biochemistry and Biotechnology 22(2):176-184.

Mazri MA, Meziani R (2015). Micropropagation of date palm: a review. Cell \&Developmental Biology 4(3):160.

Mazri MA, Meziani R, El Fadile J, Ezzinbi A (2016). Optimization of medium composition for in vitro shoot proliferation and growth of date palmcv. 'Mejhoul'. 3 Biotech 6(1):111.

Mazri MA, Belkoura I, Meziani R, Mokhless B, Nour S (2017). Somatic embryogenesis from bud and leaf explants of date palm (Phoenix dactylifera L.) cv. 'Najda’.3 Biotech 7(1):58.

MazriMA, Meziani R, Belkoura I, Mokhless B,Nour S(2018). A combined pathway of organogenesis and somatic embryogenesis for an efficient large-scale propagation in date palm (Phoenix dactylifera L.) $\mathrm{cv}$. 'Mejhoul'.3Biotech 8(4):215.

Meziani R, Jaiti F, Mazri MA, Anjarne M, Ait Chitt M, ... Alem C (2015). Effects of plant growth regulators and light intensity on the micropropagation of date palm (Phoenix dactylifera L.) cv. 'Mejhoul'. Journal ofCropScience and Biotechnology 18(5):325-331.

Meziani R, Jaiti F, Mazri MA, Hassani A, Ben Salem S, ... Alem C (2016). Organogenesis of Phoenix dactylifera L. cv. 'Mejhoul': Influences of natural and synthetic compounds on tissue browning, and analysis of protein concentrations and peroxidase activity in explants. Scientia Horticulturae 204:145-152.

MisraS (1994). Conifer zygotic embryogenesis, somatic embryogenesis, and seed germination: biochemical and molecular advances. Seed Science Research 4(4):357-384.

Murashige T, Skoog FA (1962). A revised medium for rapid growth and bioassays with tobacco tissue cultures. Phys Planta Physiologia Plantarum 15(3):473-479.

Neto VBP, Otoni WC (2003). Carbon sources and their osmotic potential in plant tissue culture: does it matter? Scientia Horticulturae 97(34):193-202.

Othmani A, Bayoudh C, Drira N, Marrakchi M, Trifi M (2009). Somatic embryogenesis and plant regeneration in date palmPhoenix dactylifer $\mathrm{L}$., cv. 'Boufeggous' is significantly improved by fine chopping and partial desiccation of embryogenic callus. Plant Cell Tissue and Organ Culture 97(1):71-79.

Othmani A, Bayoudh C, Al-Khayri JM, Drira N (2018). Cyclic somatic embryogenesis in date palm (Phoenix dactylifera L.). cv 'Deglet bey' (Mnakher). Journal of New Sciences, Agriculture and Biotechnology 5:32043213.

Rai MK, Shekhawat NS, Harish, Gupta AK, Phulwaria M, ... Jaiswal U 
(2011). The role of abscisic acid in plant tissue culture: a review of recent progress. Plant Cell Tissue and Organ Culture 106(2):179-190.

Roberts DR (1991). Abscisic acid and mannitol promote early development, maturation and storage protein accumulation in somatic embryos of interior spruce. Physiologia Plantarum 83(2):247-254.

Sané D, Aberlenc-Bertossi F, Diatta LID, Guèye B, Daher A, ... Borgel A (2012). Influence of growth regulators on callogenesis and somatic embryo development in date palm (Phoenix dactylifera L.) 'Sahelian' cultivars. The Scientific World Journal 2012:837395.

Sedra MH (2011). Development of new Moroccan selected date palm varieties resistant to Bayoud and of good fruit quality. In: Jain SM, AlKhayri JM, Johnson DV (Eds). Date palm biotechnology. Springer, Dordrecht pp 513-531.

Sedra MH (2015). Date palm status and perspective in Morocco. In: AlKhayri JM,Jain SM, Johnson DV (Eds). Date Palm Genetic Resources and Utilization. Springer, Dordrecht pp 257-323.

Shareef JH (2017). Desiccation and cold hardening of date palm somatic embryos improve germination. In: Al-Khayri JM, Jain SM, Johnson DV (Eds). Date palm biotechnology protocols Volume I. Springer Nature, New Yorkpp 119-128.

Shoji M, Sato H, Nakagawa R, Funada R, Kubo T, Ogita S (2006). Influence of osmotic pressure on somatic embryo maturation in Pinus densiflora. Journal of Forest Research 11(6):449-453.

Thorpe T, Stasolla C, Yeung EC, de Klerk GJ, Roberts A, George EF (2008). The components of plant tissue culture media II: organic additions, osmotic and $\mathrm{pH}$ effects, and support systems. In: George EF, Hall MA, De Klerk GJ (Eds). Plant propagation by tissue culture, 3rd edn. Springer,Dordrecht pp 115-173.
Thuzar M, Vanavichit A, Tragoonrung S, Jantasuriyarat C (2011). Efficient and rapid plant regeneration of oil palm zygotic embryos cv. 'Tenera' through somatic embryogenesis. Acta Physiologiae Plantarum 33(1):123-128.

Vahdati K, Bayat S, Ebrahimzadeh H, Jariteh M, Mirmasoumi M (2008). Effect of exogenous $\mathrm{ABA}$ on somatic embryo maturation and germination in Persian walnut (Juglans regia L.). Plant Cell Tissue and Organ Culture 93(2):163-171.

Von Arnold S (2008). Somatic embryogenesis. In: George EF, Hall MA, De Klerk GJ (Eds). Plant propagation by tissue culture, 3rd edn. Springer, Dordrecht pp 335-354.

Yaseen M, Ahmad T, Sablok G, Standardi A, Hafiz IA (2013). Review: role of carbon sources for in vitro plant growth and development. Molecular Biology Reports 40(4):2837-2849.

Zaid A, Al Kaabi H (2003). Plant-off types in tissue culture-derived date palm (Phoenix dactylifera L.). Emirates Journal of Food and Agriculture 15(1):17-35.

Zhang CX, Li Q, Kong L (2007). Induction, development and maturation of somatic embryos in Bunge's pine (Pinus bungeana Zucc. ex Endl.). Plant Cell Tissue and Organ Culture 91(3):273-280.

Zouine J, El Bellaj M, Meddich A, Verdeil JL, El Hadrami I (2005). Proliferation and germination of somatic embryos from embryogenic suspension cultures in Phoenix dactylifera. Plant Cell Tissue and Organ Culture 82(1):83-92.

Zouine J, El Hadrami I (2007). Effect of 2,4D, glutamine and BAP on embryogenic suspension culture of date palm (Phoenix dactylifera L.). Scientia Horticulturae 112(2):221-226. 